\title{
Fare Policy and Vertical Equity: The Trade-off between Affordability and Cost Recovery
}

\author{
Xavier J. Harmony \\ Northeast Corridor Commission
}

\begin{abstract}
Vertical equity and the maximization of farebox revenue are important but conflicting goals in the development of fare policy in the United States. Reducing fares for low-income riders reduces revenue for a transit agency, while increasing fares could disproportionately impact lower-income riders. This paper details this conflict, explores strategies that could account for both goals, and evaluates fare programs in the United States. Two types of low-income strategies are discussed: first generation strategies and targeted subsidy strategies. First generation strategies have several limitations that targeted subsidy strategies account for; first generation strategies focus more on supply, while targeted subsidy strategies focus more on demand. The evaluation of US low-income fare programs found that organizational partnerships can reduce administrative and financial impacts to agencies, local ridership characteristics need to be considered in designing a program, and that smart card technology is useful but not required to create a targeted subsidy program.
\end{abstract}

Keywords: transit fare policy, reduced fares, equity, low-income

\section{Introduction}

Increased urbanization around the world has created a reliance on increasingly efficient transportation systems to move people and goods. An efficient method for moving people, particularly in high-density areas, is transit. Consequently, an effective transit system is an integral part of a robust transportation system. However, there are many trade-offs in the development of these systems, one of which occurs when transit agencies try to account for the needs of their vulnerable users while minimizing costs. This paper examines the contrast between the issues of vertical equity and cost recovery in transit fare policy in four sections. First, a brief summarization of key literature provides a background of the two issues to enable a better understanding of vertical equity and fare policy. The second section employs existing literature to describe different strategies

(C) 2018 Xavier J. Harmony

http//dx.doi.org/10.5038/2375-0901.21.2.3

ISSN: 1077-291X | Licenced under Creative Commons License Attribution - Noncommercial 4.0

The Journal of Public Transportation is published by the Center for Urban Transportation Research at the University of South Florida 
that have been tried to address the issues. The third section expands on the discussion by evaluating various approaches to low-income fare strategies in the United States. Finally, the last section summarizes lessons learned, recommendations, and suggestions for future work.

\section{Background}

Fares affect all parts of a transit system including revenue generation, the perception of transit in a community, and ridership (Fleishman 2012). Hence, the development of fare policy is a complicated process that involves the consideration of many goals, some of which are described in Table 1 (Fleishman 2012).

\section{TABLE 1.}

Fare Related Goals

\begin{tabular}{|l|l|}
\hline \multicolumn{1}{|c|}{ Goal } & \multicolumn{1}{c|}{ Description } \\
\hline $\begin{array}{l}\text { Improve } \\
\text { Convenience/Ease } \\
\text { of Access }\end{array}$ & Simplifying fare payment makes transit more accessible and easier to use. \\
\hline Influence Demand & $\begin{array}{l}\text { Changes in fare structure can influence peaking characteristics for transit demand. } \\
\text { This can make peak periods easier for agencies to manage. }\end{array}$ \\
\hline $\begin{array}{l}\text { Insure Fares Are } \\
\text { Equitable }\end{array}$ & $\begin{array}{l}\text { Equitable fares provide different pricing levels depending on socioeconomic or } \\
\text { demographic characteristics. }\end{array}$ \\
\hline $\begin{array}{l}\text { Maintain/Increase } \\
\text { Revenue }\end{array}$ & $\begin{array}{l}\text { Pricing economics explains how optimal revenue can be generated through an } \\
\text { understanding of how many people are willing to use the service given a certain } \\
\text { price. }\end{array}$ \\
\hline $\begin{array}{l}\text { Maintain/Increase } \\
\text { Ridership }\end{array}$ & $\begin{array}{l}\text { Related to the previous goal, a reduced price may increase ridership; conversely, an } \\
\text { increased price may reduce ridership. }\end{array}$ \\
\hline $\begin{array}{l}\text { Maximize Prepay/ } \\
\text { Minimize Cash }\end{array}$ & $\begin{array}{l}\text { Minimizing cash has operational benefits such as reducing boarding delay and } \\
\text { reducing the need for customers to always have cash on them. }\end{array}$ \\
\hline $\begin{array}{l}\text { Reduce Agency } \\
\text { Administration }\end{array}$ & Reduces the work required by an agency to manage the fare payment system. \\
\hline $\begin{array}{l}\text { Relate Fare to } \\
\text { Cost of Service }\end{array}$ & As costs for providing for the service increase, the price of fares also increases. \\
\hline $\begin{array}{l}\text { Relate Fare to } \\
\text { Distance Traveled }\end{array}$ & $\begin{array}{l}\text { Fares can be linked to travel distance so the farther customers travel, the more } \\
\text { they pay. }\end{array}$ \\
\hline
\end{tabular}

As Table 1 shows, there are many different goals that could be prioritized when developing fare policies and many of these goals could affect the equity-revenue trade-off problem explicitly or implicitly. Relating fares to distance traveled is an example of an implicitly related goal; it may make costs more equal but not necessarily equitable. Lower income households are often located away from job centers resulting in low-income individuals having to travel farther (Kneebone and Holmes 2015), so a location-based fare means they may be disproportionately impacted by this fare goal. While implicit goals are important and potentially impactful to the trade-off problem, this paper focuses on fare policy goals that explicitly focus on revenue and equity: "Maintain/Increase Revenue" and "Insure Fares Are Equitable." The next section specifically focuses on factors that could influence these goals. 


\section{Revenue and Cost Recovery}

Cost recovery for a transit system is an agency's ability to use revenue to cover the costs for providing a service. This concept is a function of both farebox revenue and operating costs and is measured using the farebox recovery ratio. This measure is the ratio of farebox revenue as a proportion of total operating expenses. For example, if farebox revenue is $\$ 25$ million and operating expenses are $\$ 100$ million, the farebox recovery ratio would be 0.25 . In the United States, the median farebox revenue for major transit systems is approximately 0.35 (Lindquist, Wendt, and Holbrooks 2009). This means the remaining $65 \%$ of operating expenses must be accounted for elsewhere.

Funding sources for transit systems in the United States consist of a variety of revenue streams that could make up funding gaps. Other than fare revenue, transit agencies are primarily funded using local, state, and federal government money. However, the reliance on government money to subsidize transit agencies has been criticized for several reasons, including financial mismanagement, reduced incentives for innovation and initiatives, and reduced competition (Kockelman et al. 2013). Consequently there is pressure to reduce government subsidies through maximizing farebox recovery ratios.

Increasing farebox recovery ratios and decreasing the reliance on government subsidies could happen through increasing fares, increasing ridership, or decreasing operating costs (MBTA n.d.). The first two factors are influenced by pricing economics; an understanding of how supply and demand affect price. The basic relationship between supply and demand is shown in Figure 1.

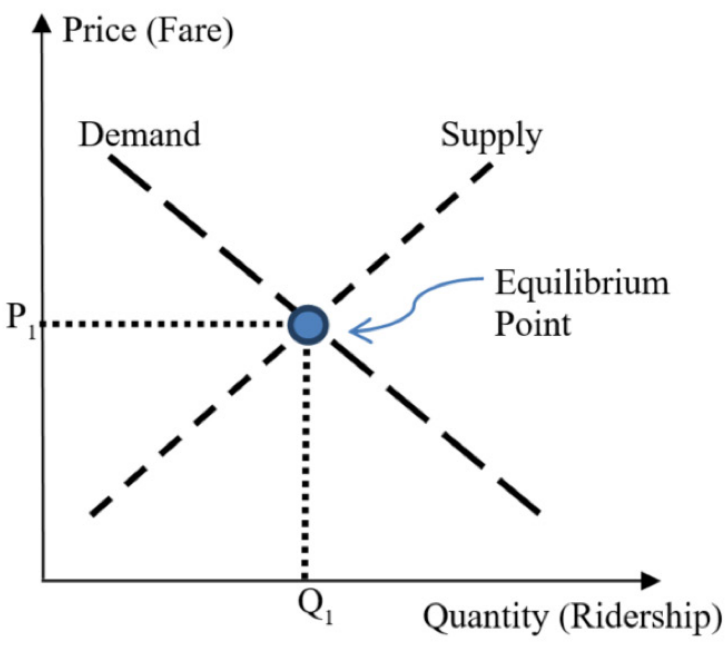

FIGURE 1.

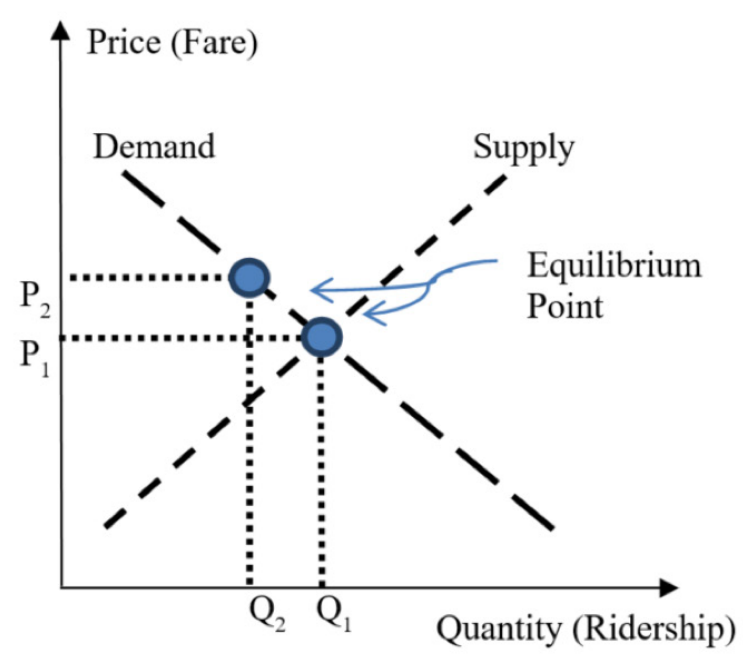

b)

Equilibrium price (a) and change in price (b)

Figure 1(a) shows how supply and demand curves interact. In this case, supply is the quantity of transit available to be used while demand is the amount of transit customers desire. Where the two lines meet is called an equilibrium point or equilibrium price. It is where both supply and demand have the same price of a good or service, $\mathrm{P}_{1}$, for the same quantity, $\mathrm{Q}_{1}$. For transit, quantity would be the number of people willing to 
use the service (i.e., ridership), while price would be what people are willing to pay for the service (the fare). The equilibrium point is the fare price agencies are willing to charge to attain a certain ridership. If the price is increased, $P_{2}$, the number of people willing to pay decreases, as shown in Figure 1(b). The figures show that fares and ridership are intricately related, complicating decisions to increase fares. Increasing fares too much can significantly reduce ridership, resulting in a variety of impacts including increased congestion, reduced environmental benefits, and decreased economic development (APTA 2007). Such a price change would particularly impact low-income households.

Ridership could be increased by decreasing fares, potentially reducing overall revenue, or by making transit more appealing. By increasing the system's perceived value, the demand curve shown in Figure 1 would move to the right, meaning both ridership and the equilibrium price would increase. The perceived value of the system could be increased through many changes including increased reliability, increased service, and newer vehicles (Gray and Hoel 1992). However, many of these changes require increased spending, which may negate any benefits ridership may have on the farebox recovery ratio. In addition, many transit agencies have reported that changes in ridership are more subject to external influences, such as changes in economic conditions, than to internal influences (Gomez-lbanez 1996). Finally, this strategy could also negatively impact low-income households who may need to use transit regardless of how it is perceived. So, if the perceived value of the system improves and the equilibrium price increases, the system may become less affordable for low-income customers.

Reducing costs for operating a transit system is another avenue for increasing farebox recovery ratios, but this strategy is also difficult to achieve. Labor costs account for over $80 \%$ of operating costs for transit agencies in the United States (GAO 2001); hence, decreasing costs requires either reducing labor pay, especially difficult due to the relationship with transit unions (Oestreich and Whaley 2001), or decreasing service frequency or coverage. Decreasing services would reduce operating costs but could also reduce ridership and the perceived value of the system, resulting in potentially negligible benefits for farebox recovery ratios.

While transit agencies are under pressure to increase farebox recovery ratios to reduce reliance on other funding streams, achieving this is complicated and difficult. Many strategies that could affect farebox recovery ratios induce risks of increased costs, disproportionate impacts on vulnerable customers, and reduced services. Consequently, creative strategies for increasing farebox recovery ratios are needed.

\section{Vertical Equity in Transit}

Vertical equity focuses on how the impacts of a decision affect different income groups and social classes (Camporeale et al. 2017). Policies that account for vertical equity distribute impacts across these different groups in a fair way (Bueno Cadena et al. 2016); those who are able should pay more. For transit this means the impact of paying for a service depends on how different socioeconomic groups are affected.

Transit systems can benefit all income groups, but they are particularly important for low-income households. The availability of transit systems increases accessibility to jobs, education, and other amenities for individuals in low-income groups (Criden 2008). Low-income households are also less likely to have access to a private vehicle and have less disposable income, making them more captive to transit (Beimborn, Greenwald, and Jin 2003). The idea of low-income populations being captive to transit is supported by previous research demonstrating that as income increases, ridership decreases (Gomez-lbanez 1996; Taylor and Fink 2003; Urban Transport Group 2010). However, low-income customers have unique needs that provide challenges for transit agencies. For example, many lower-income jobs require employees to work odd 
hours making it difficult for transit to meet their needs (Criden 2008). These demands put pressure on transit agencies to increase service times and frequencies, further increasing costs to the agencies and, consequently, incentivizing fare increases.

Overall, riders with lower incomes often rely on transit more while contributing to increased costs for transit systems. Although these groups significantly impact a transit system, they are also especially vulnerable to fare increases, so agencies need to carefully account for them when developing fare policies.

\section{The Trade-off}

As this paper has so far shown there are two opposing fare policy goals, each with their own challenges for transit agencies. Meeting these goals is increasingly causing transit agencies to pay greater attention to equity issues when developing fare policies (Multisystems, Inc. 2003). While transit agencies are pressured to reduce reliance on government subsidies by increasing their farebox recovery ratio, doing so involves many potential impacts for vulnerable transportation users. These vulnerable users generate additional complications by causing greater demands on the system and using transit at a higher rate than other socioeconomic groups. Nevertheless, both problems can be considered together if transit agencies treat vulnerable customers separately. As mentioned, one potential strategy for increasing farebox recovery ratios is to increase revenue, which would affect low-income groups disproportionately. However, if these groups were excluded from the fare increases, revenue might be increased while limiting the impact on vulnerable users. This could benefit both fare goals.

\section{Strategies}

The direct trade-off between low-income households and farebox recovery has shown that transit agencies need to strategize how to account for both issues. Many of the existing programs offered by agencies to make transit more affordable are not necessarily accessible to low-income households. For example, a weekly or monthly ticket may cost less than buying individual tickets over the same time period, but the purchase of one of these tickets requires a greater up-front lump sum, which is more difficult for low-income households to manage (Urban Transport Group 2010).

Transit agencies need to consider how they can make transit more affordable to low-income passengers. When developing fare strategies and policies, they can follow four steps to help ensure the strategies meet their intended goals (Mehndiratta, Rodriguez, and Ochoa 2014):

1. Define who needs support.

2. Understand how people travel.

3. Analyze how a scheme affects accessibility and financial sustainability.

4. Determine how to avoid fraud and other unintended consequences. (Unintended consequences often include inclusion or exclusion problems. These occur when a strategy includes some people who do not require subsidization or excludes others who require subsidization but are neglected by the strategy.)

The two types of fare strategies, first generation programs and targeted subsidy programs, were first identified and described by a paper from the World Bank (Mehndiratta, Rodriguez, and Ochoa 2014). Both strategies have unique benefits and limitations in targeting low-income populations. 


\section{First Generation Subsidy Programs}

The trade-off problem is not a new issue and there have been several attempts to address it around the world. These first attempts are known as first generation subsidy programs, and they did not always meet their intended goals. Table 2 summarizes some of the previous attempts to account for low-income households, while also identifying limitations of the strategies (Mehndiratta, Rodriguez, and Ochoa 2014).

\section{TABLE 2.}

Examples of First Generation Subsidy Programs

\begin{tabular}{|c|c|c|c|}
\hline Strategy & Description & Limitations & Examples \\
\hline $\begin{array}{l}\text { Free Feeder } \\
\text { Lines }\end{array}$ & $\begin{array}{l}\text { Free transit connects poorer } \\
\text { neighborhoods to other } \\
\text { transit or neighborhoods. }\end{array}$ & $\begin{array}{l}\text { - Excludes low-income } \\
\text { populations in other } \\
\text { geographic locations } \\
\text { - May increase spatial } \\
\text { segregation }\end{array}$ & $\begin{array}{l}\text { Rio de Janeiro, Brazil; } \\
\text { Medellin, Colombia }\end{array}$ \\
\hline $\begin{array}{l}\text { Subsidized } \\
\text { Transfers }\end{array}$ & $\begin{array}{l}\text { Fare cards cap the fare } \\
\text { for multi-modal trips. As } \\
\text { low-income households } \\
\text { are often located in outer } \\
\text { suburbs where housing is } \\
\text { more affordable, they may be } \\
\text { subject to more transfers. }\end{array}$ & $\begin{array}{l}\text { - Encourages urban sprawl } \\
\text { - Inclusion problems: } \\
\text { not everyone who } \\
\text { uses multiple transfers } \\
\text { comes from low-income } \\
\text { households }\end{array}$ & $\begin{array}{l}\text { Rio de Janeiro, Brazil; } \\
\text { Sao Paulo, Brazil }\end{array}$ \\
\hline $\begin{array}{l}\text { Subsidized } \\
\text { Fares for } \\
\text { Demographics }\end{array}$ & $\begin{array}{l}\text { Lower fares are available for } \\
\text { demographic groups that may } \\
\text { have fixed or low incomes. } \\
\text { Examples include students } \\
\text { and the elderly. }\end{array}$ & $\begin{array}{l}\text { - Exclusion problems: } \\
\text { some low-income people } \\
\text { may not be included } \\
\text { in the subsidized } \\
\text { demographics } \\
\text { - Inclusion problems: } \\
\text { some people included } \\
\text { in the demographics } \\
\text { may not require fare } \\
\text { subsidization }\end{array}$ & $\begin{array}{l}\text { Various examples } \\
\text { around the world }\end{array}$ \\
\hline
\end{tabular}

As the examples in Table 2 show, some of these strategies have violated some of the steps for developing equity strategies that were described earlier. First generation programs do not always specifically define who needs support, do not comprehensively understand travel patterns of low-income communities, and include many unintended consequences that could exacerbate problems that have not been accounted for.

\section{Targeted Subsidy Programs}

Program limitations of the first generation of strategies led to targeted subsidy programs that were better able to account for these limitations. A critical difference between these two types is that targeted subsidy programs focus on the demand for transit rather than supply (Mehndiratta, Rodriguez, and Ochoa 2014). For example, the free feeder lines mentioned in Table 2 provide additional transit supply in low-income communities, where service is the policy focus. Targeted subsidy programs focus instead on the people who would use the system, the transit demand. Two primary factors have contributed to the uptake of targeted subsidy programs (Mehndiratta, Rodriguez, and Ochoa 2014): 
- Increased understanding of how to identify target populations

- The advent of smart card technology

A major limitation of previous programs was the difficulty in identifying target populations. However, many cities and governments have since developed socioeconomic indicators, such as income and household demographic composition, which define and identify low-income populations (Mehndiratta, Rodriguez, and Ochoa 2014). These indicators have been used to identify low-income populations for various other social programs so strategies based on them would be beneficial. A better understanding of what constitutes a lowincome person leads to better targeted policy development.

The development of electronic fare systems, especially the use of smart cards, have made targeting people for specific policies easier (Mehndiratta, Rodriguez, and Ochoa 2014). Smart cards have many advantages that could benefit low-income policies in transit. For example, smart cards can be personalized, allowing for subsidies to directly target a person while reducing the risk of fraud, and they can be uniform in appearance, potentially removing any stigma associated with requiring fare assistance.

As the description of targeted subsidy programs demonstrates, they are an improvement over first generation programs. Through a better understanding of who needs support, agencies can more easily avoid unintended consequences such as inclusion and exclusion errors. The next section evaluates fare programs in the United States to reveal trends in agencies implementing strategies aimed at assisting low-income populations.

\section{Fare Programs in the United States}

Fare programs in the United States were evaluated by two methods in this paper: (1) analyzing a dataset of US fare policies to identify patterns between transit organizations offering different types of strategies, and (2) exploring case studies to demonstrate different types of strategies and their impacts.

\section{Analysis of US Fare Programs}

The Community Transportation Association originally assembled the list of fare programs used in this analysis. The organization summarized 94 worldwide programs that provided reduced or free fares aimed at low-wage earners (Community Transportation Association 2011). This original dataset was narrowed to include US-only programs, reducing the total number of programs to 80 . Finally, the data were cleaned by ensuring programs met three requirements: (1) the service had to be made available to the general public; (2) the service had to have a fixed-route component; and (3) information about the service had to be publicly available. These requirements reduced the number of programs to 61 .

Characteristics selected for analysis were primarily based on transit agency size and resources. The justification was that larger agencies with more resources might be better able to define who their customers are and have the technology to specifically target low-income populations, requirements for targeted fare strategies. The data were collected from agency websites and the Federal Transit Administration's National Transit Database (NTD). The following variables were included in the dataset:

- Agency - The name of the agency providing the transit service.

- Program Type - Fare program category determined, based on information from agency websites. Types include: 
- First Generation - agencies that provide first generation programs only

- Targeted - agencies that include targeted subsidy programs (all agencies that provided targeted programs also provided first generation programs)

- Free - agencies that provided service without fares

- Smart Card - Categorical variable stating whether an agency uses smart card technology. This information was determined based on information from agency websites.

- Square Miles - The service area covered by the agency (information obtained from NTD).

- Population - The estimated population covered by the service area (information obtained from NTD).

- Population/Square Mile - Population density calculated by dividing "Population" by "Square Miles"

- Buses Operated - The number of buses operated by the agency (information obtained from NTD).

- Operating Expenses - The total operating expenses of the agency (for fiscal year 2014; information obtained from NTD).

After collection the data were analyzed using a univariate analysis. This method was chosen since the primary purpose of the analysis was to identify descriptive patterns in the characteristics of agencies that provide different fare strategies. It must be noted that information for Square Miles, Population, Population/Square Mile, Buses Operated, and Operating Expenses was not available for all agencies. Agencies providing free fares were particularly unrepresented for these variables.

\section{Results}

Targeted subsidy pricing strategies accounted for approximately $20 \%$ of all fare programs recorded in the dataset, as shown in Figure 2. Free fare programs and other first generation programs each accounted for approximately $40 \%$. It is not unexpected that agencies providing targeted programs represent the fewest agencies as these types of programs are newer and are more difficult to design and implement.

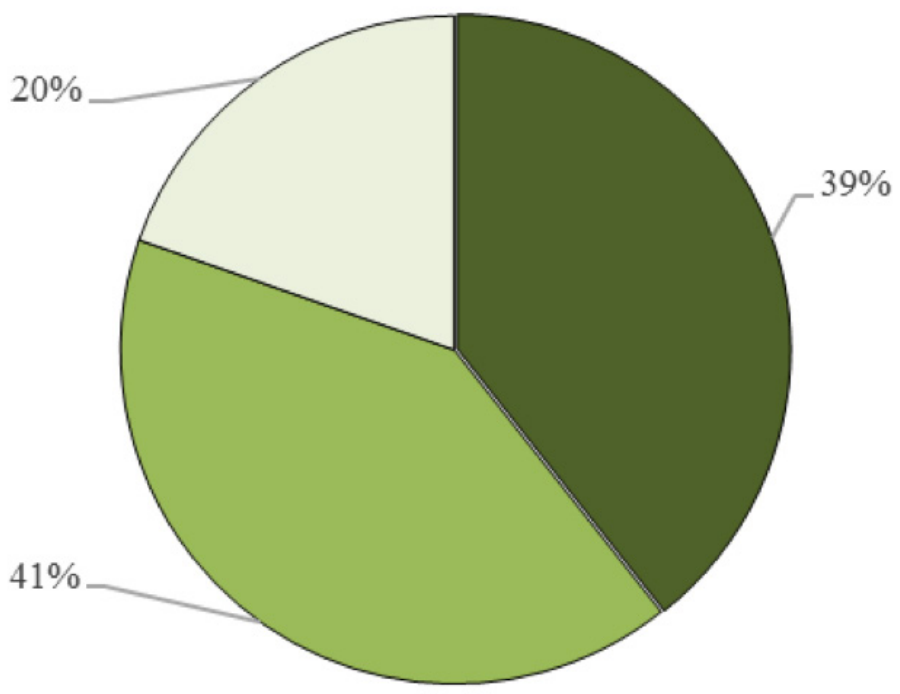

\section{First Generation}

$\square$ Free

\section{FIGURE 2.}

Low-income fare program types $(n=61)$ 
Figure 3 shows the proportion of transit agencies that use smart cards. While an absence of smart cards is more prevalent for agencies offering first generation fare programs, half of agencies providing targeted fare programs also did not use smart cards, higher than expected considering the literature. No fare payment system is required for agencies that do not have fares.

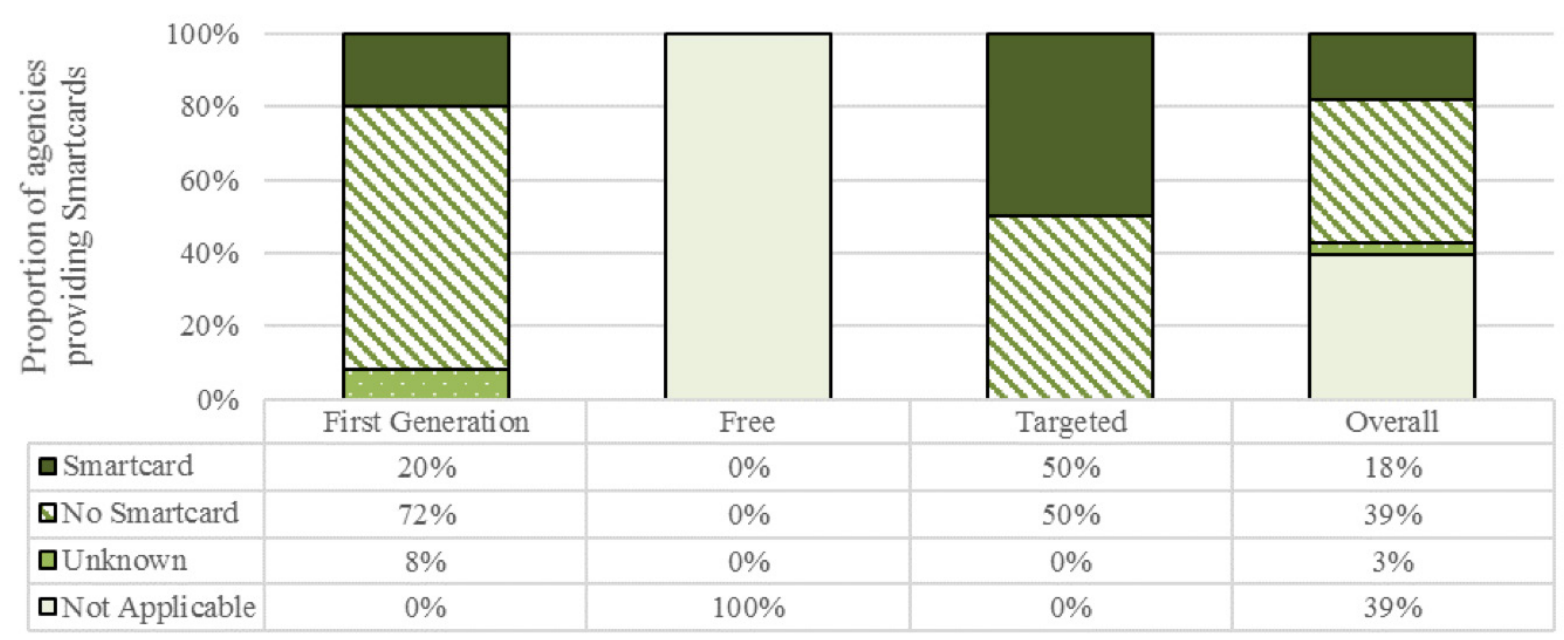

\section{FIGURE 3.}

Smart card use in low-income fare programs $(n=61)$

Table 3 lists the results of the univariate analysis of agency characteristics. Figures 4 through 8 show the results for each type of fare program and each type of agency characteristic plotted on box plots to easily identify patterns in spread. For graphic clarity, some of the axes have been cropped, removing some of the outliers in first generation strategies. 


\section{TABLE 3.}

Analysis Results

\begin{tabular}{|c|c|c|c|c|}
\hline \multirow{2}{*}{ Variable } & \multirow{2}{*}{ Statistic } & \multicolumn{3}{|c|}{ Value for Each Fare Strategy Type } \\
\hline & & First Generation & Free & Targeted \\
\hline \multirow{7}{*}{$\begin{array}{l}\text { Operating Expenses } \\
\text { (\$ Millions) }\end{array}$} & Count & 18 & 10 & 11 \\
\hline & Minimum & $\$ 1.2$ & $\$ 1.3$ & $\$ 8.5$ \\
\hline & First Quartile & $\$ 4.4$ & $\$ 1.7$ & $\$ 25.5$ \\
\hline & Median & $\$ 25.8$ & $\$ 2.9$ & $\$ 33.3$ \\
\hline & Third Quartile & $\$ 100.0$ & $\$ 3.4$ & $\$ 226.2$ \\
\hline & Maximum* & $\$ 213.0$ & $\$ 4.9$ & $\$ 392.3$ \\
\hline & Mean & $\$ 240.9$ & $\$ 4.1$ & $\$ 147.4$ \\
\hline \multirow{7}{*}{$\begin{array}{l}\text { Bus Operation Size } \\
\text { (Number of Buses) }\end{array}$} & Count & 18 & 10 & 11 \\
\hline & Minimum & 3 & 1 & 22 \\
\hline & First Quartile & 15 & 4 & 60 \\
\hline & Median & 52 & 10 & 86 \\
\hline & Third Quartile & 176 & 19 & 281 \\
\hline & Maximum* & 350 & 26 & 516 \\
\hline & Mean & 207 & 17 & 228 \\
\hline \multirow{7}{*}{$\begin{array}{l}\text { Service Area } \\
\text { (Square Miles) }\end{array}$} & Count & 18 & 10 & 11 \\
\hline & Minimum & 25.0 & 10.0 & 41.0 \\
\hline & First Quartile & 70.5 & 14.8 & 90.5 \\
\hline & Median & 238.0 & 37.0 & 170.0 \\
\hline & Third Quartile & 502.5 & 83.0 & 635.0 \\
\hline & Maximum* & $3,519.0$ & 90.0 & $1,087.0$ \\
\hline & Mean & 670.1 & 102.9 & 498.9 \\
\hline \multirow{7}{*}{$\begin{array}{l}\text { Service Population } \\
\text { (Number of People) }\end{array}$} & Count & 18 & 10 & 11 \\
\hline & Minimum & 46,000 & 7,000 & 68,000 \\
\hline & First Quartile & 80,500 & 28,500 & 232,500 \\
\hline & Median & 262,000 & 63,000 & 382,000 \\
\hline & Third Quartile & $1,330,750$ & 80,750 & $1,713,000$ \\
\hline & Maximum* & $1,425,000$ & 97,000 & $2,874,000$ \\
\hline & Mean & $2,031,000$ & 56,000 & 927,000 \\
\hline \multirow{7}{*}{$\begin{array}{c}\text { Service Density } \\
\text { (Population per } \\
\text { Square Mile) }\end{array}$} & Count & 18 & 10 & 11 \\
\hline & Minimum & 484.0 & 13.1 & 638.1 \\
\hline & First Quartile & $1,677.9$ & 13.1 & $1,701.6$ \\
\hline & Median & 2,117.1 & $1,467.0$ & $2,529.7$ \\
\hline & Third Quartile & $2,854.3$ & $2,324.0$ & $2,768.3$ \\
\hline & Maximum* & $3,476.8$ & $3,949.9$ & $3,965.0$ \\
\hline & Mean & $2,371.5$ & $1,671.8$ & $2,303.0$ \\
\hline
\end{tabular}

*Maximum values are the lesser of the data maximum and the third quartile added to 1.5 multiplied by the interquartile range 
As the figures show, the spread of data for first generation and targeted strategies overlaps significantly, suggesting there are not many differences in agency characteristics between the two types of strategies. However, the box plots for targeted strategies generally had a larger spread with similar minimums, indicating they were more likely to record higher observations for each of the different characteristics. This is consistent with the initial justification for choosing the variables, although the pattern is less pronounced than expected. Agencies with free fares consistently had the lowest observed observations for each characteristic, as expected.

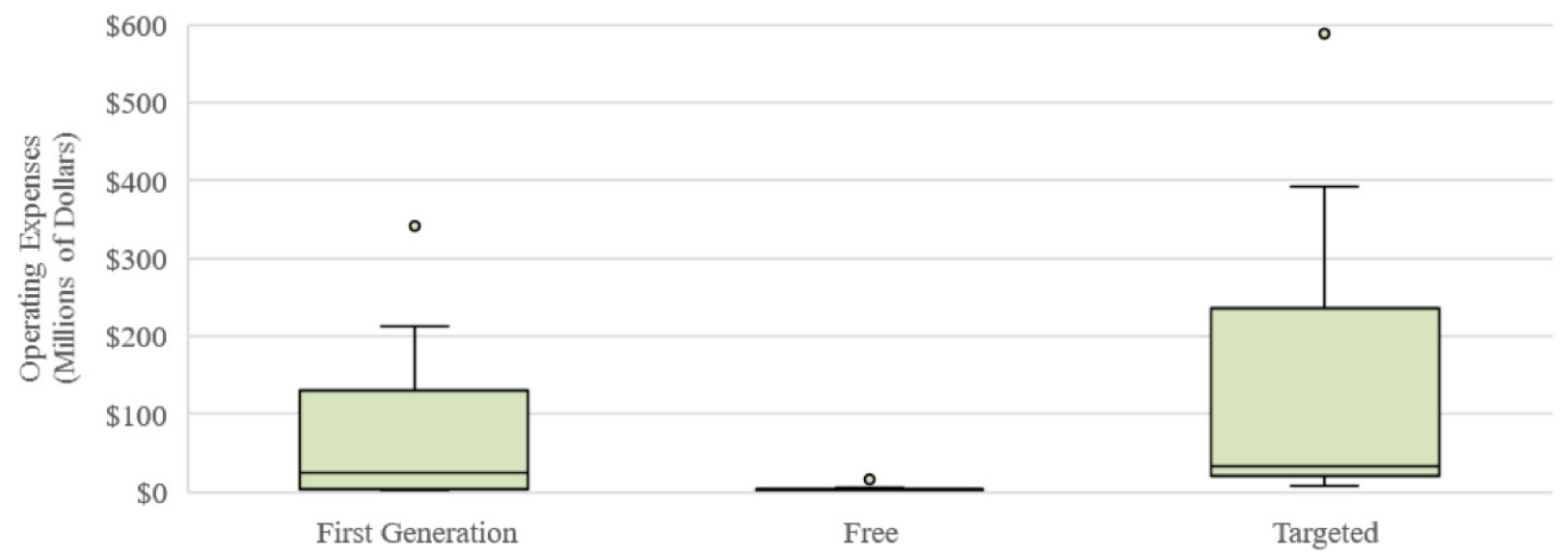

FIGURE 4.

Operating expenses of low-income fare program types

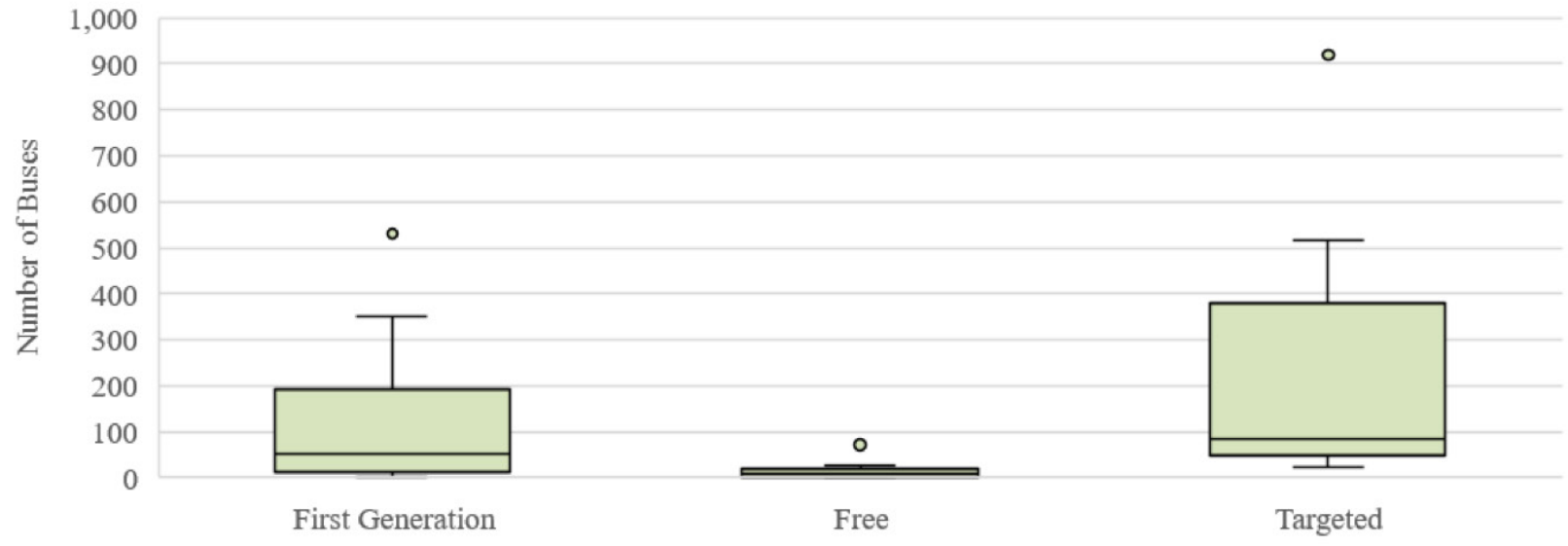

FIGURE 5.

Bus operation sizes of low-income fare program types 
Fare Policy and Vertical Equity: The Trade-off between Affordability and Cost Recovery

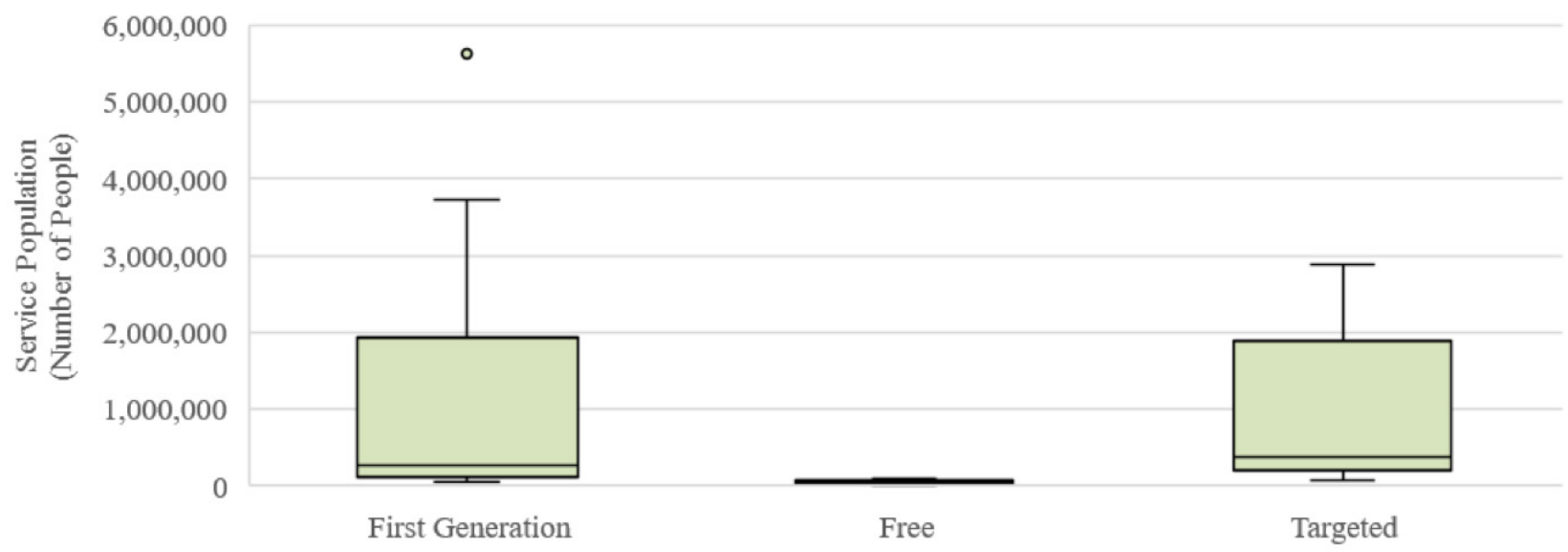

\section{FIGURE 6.}

Service populations of low-income fare program types

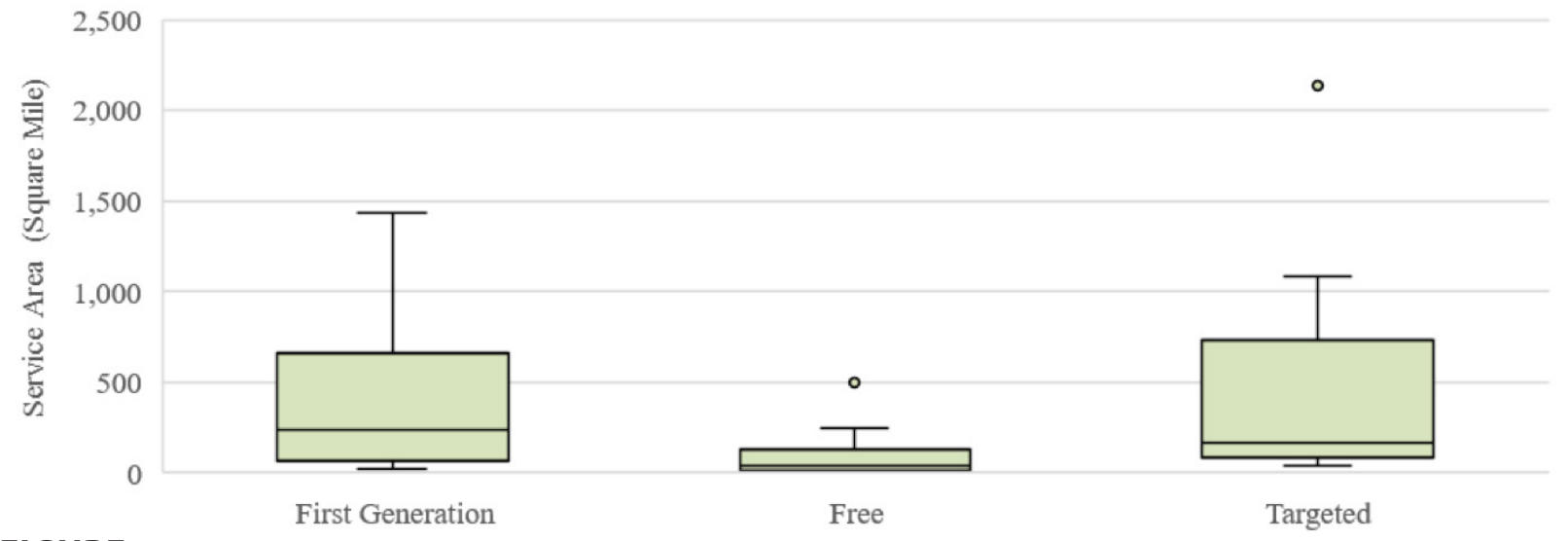

\section{FIGURE 7.}

Service areas of low-income fare program types

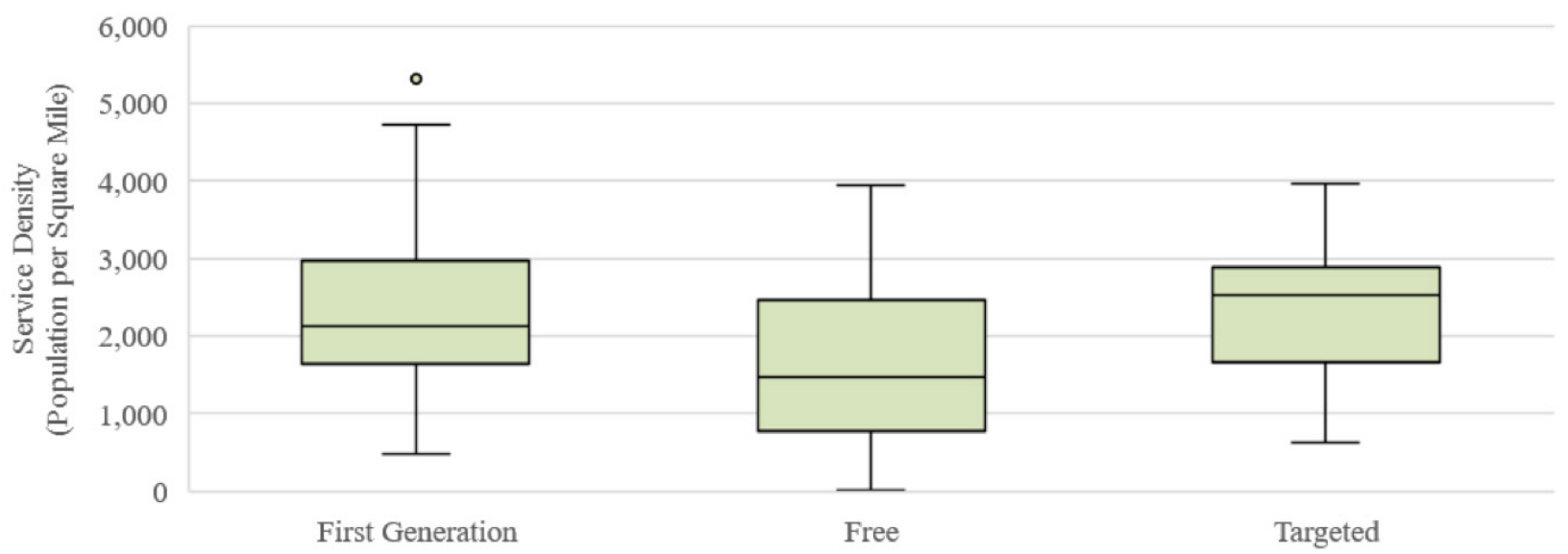

FIGURE 8.

Service densities of low-income fare program types 
Fare Policy and Vertical Equity: The Trade-off between Affordability and Cost Recovery

\section{Case Studies}

The following case studies show details of different fare strategies while demonstrating their financial impacts. Three case studies are explored: Heritage Community Transportation, Pennsylvania; King County Metro, Washington; and TriMet, Oregon. It is worth noting that these case studies are not intended to provide a critique of the identified agencies, but instead highlight potential limitations with existing low-income fare strategies.

\section{Case Study 1: Heritage Community Transportation, Pennsylvania}

Heritage Community Transportation is a fixed-line bus service in Monongahela Valley in Greater Pittsburgh, Pennsylvania (locally known as "Mon Valley"). Fares are $\$ 0.25$ per ride for adults and $\$ 0.10$ per ride for children and people with disabilities, providing an affordable option for a ridership with $63 \%$ living on less than $\$ 10,000$ a year (Transportation for America n.d.) and $97 \%$ with no alternative method to get to work (Heritage Community Initiatives 2012). The program is primarily funded by the federal and state governments (Transportation for America n.d.). Although this is counter to the pressures on revenue described previously, it does mean that the availability of such a system offsets costs of adjacent transit systems, like the Port Authority of Allegheny County (Port Authority). The Port Authority is the local transit system for Pittsburgh and surrounding areas, including the Mon Valley area. The existence of the Heritage Community Transportation system means the Port Authority does not have to provide service coverage or frequency to all the lower-income areas the Heritage Community Transportation program covers. This reduces system costs and potentially benefits the agency's farebox recovery ratio. As the Port Authority does not run this system, the financial impact on the agency's operating expenses is difficult to quantify. In addition to this, the Heritage Community Transportation program contributed to a $\$ 132$ million economic benefit for the local economy due to increased job access and spending power for the serviced communities (Transportation for America n.d.).

However, the Heritage Community Transportation program uses first generation strategies and does have a few limitations. The program is essentially a free feeder line, similar to the examples given in Table 2, and is subject to exclusion and inclusion issues; it excludes low-income populations living outside the Mon Valley area, while including wealthier people living within the service area.

Case Study 2: King County Metro, Washington

King County Metro (Metro) in Washington State originally had only first generation fare programs. Beginning in 1973, the agency introduced discounted fares for youth and seniors, extending to people with disabilities in 1976 (King County Metro 2014). However, in 2013, the county created a Low-Income Fare Options Advisory Committee to specifically target low-income populations (King County Metro 2014), approximately $24 \%$ of Metro's ridership (King County Metro 2015). This committee identified the need for a low-income fare program, an example of a targeted subsidy program, which was eventually named ORCA LIFT and implemented in 2015. ORCA LIFT was designed to have a flat fee for individuals whose incomes were at or below $200 \%$ of the federal poverty level. The fee, currently $\$ 1.50$, allows low-income riders to save more than $50 \%$ of their fare depending on the trip (King County Metro 2014). People who qualify for the program must prove their income at an enrollment location to obtain an ORCA LIFT pass, which is then useable for 24 months regardless of earnings. 
Although this policy specifically benefits low-income households, it negatively impacts the revenue for Metro. The strategy is expected to cost the agency approximately $\$ 4.75$ million in financial year (FY) 2016/2017. However, as Metro's farebox recovery ratio is approximately 0.29 and operating costs are around $\$ 650$ million (FY 2013), the impact of this strategy would account for only about $0.7 \%$ of the agency's overall operating budget (FTA 2013). This demonstrates a relatively low financial impact to the agency.

Case Study 3: TriMet, Oregon

TriMet in Oregon also offers assistance for low-income commuters with their Fare Assistance Program. Unlike Metro, TriMet works directly with nonprofit organizations to provide the program, reducing the administration load for the agency. Eligible organizations register with the agency to indicate they work with low-income populations, defined by TriMet as those at or below $150 \%$ of the federal poverty level, approximately $13 \%$ of TriMet's ridership (TriMet 2016b), and would like to offer fare assistance. Once an organization has been approved by TriMet, the agency provides low-cost or free passes to the nonprofit organizations to distribute to their clients (TriMet n.d.a).

A limitation of the TriMet system is a consequence of the agency's Fare Assistance funding setup. TriMet allows only $\$ 1.5$ million for its low-income fare programs, constraining the number of organizations that could allocate the cheaper fare passes. However, the low cost means the program does not substantially impact TriMet's operating costs. The most recent available information shows the agency has a farebox recovery ratio of approximately 0.27 (FTA 2014) and is anticipating operating costs of approximately \$511.3 million in FY 2017 (TriMet 2016a); consequently, the financial impact of the strategy accounts for only about $0.3 \%$ of the operating budget.

In addition to the Fare Assistance Program, TriMet utilizes other strategies that ensure low-income populations are not disproportionately affected by agency policies. For example, any adverse changes to the service provided by the agency, such as a decrease in frequency or hours of service, are evaluated against the impacts to lowincome populations (TriMet n.d.b).

\section{Current Practice Solutions}

The literature and fare strategies described in this paper identify a few key requirements for making a lowincome fare policy successful:

- Defining the low-income populations

- Identifying the low-income populations

- Providing the targeted populations with lower fares

- Preventing or reducing possible fraud

Table 4 lists current practice solutions for each of these requirements using information from agency websites. 


\section{TABLE 4.}

Targeted Strategy Current Practice

\begin{tabular}{|c|c|}
\hline Strategy Characteristic & Current Practice Examples \\
\hline $\begin{array}{l}\text { Methods to define low- } \\
\text { income populations }\end{array}$ & $\begin{array}{l}\text { - Customers at or below } 150 \% \text { of the federal poverty level } \\
\text { - Customers at or below } 200 \% \text { of the federal poverty level } \\
\text { - People who are employed and meet federal low-to-moderate } \\
\text { income guidelines }\end{array}$ \\
\hline $\begin{array}{l}\text { Methods to identify low- } \\
\text { income populations }\end{array}$ & $\begin{array}{l}\text { - Customers present a card from another social welfare program (e.g. } \\
\text { food stamps) } \\
\text { - Recent paystubs } \\
\text { - Letter from an employer } \\
\text { - Copy of most recent tax return } \\
\text { - Employment Security verification }\end{array}$ \\
\hline $\begin{array}{l}\text { Methods to provide reduced } \\
\text { fares for low-income } \\
\text { populations }\end{array}$ & $\begin{array}{l}\text { - Produce a low-income smart card or allow a smart card belonging to } \\
\text { a low-income customer to have different pricing } \\
\text { - Provide a low-income eligibility card for customers to purchase } \\
\text { cheaper travel passes } \\
\text { - Provide discounted passes to organizations that work with low- } \\
\text { income populations }\end{array}$ \\
\hline $\begin{array}{l}\text { Methods to reduce or } \\
\text { prevent fraud }\end{array}$ & $\begin{array}{l}\text { - Provide short-term (e.g., } 31 \text { day) passes that require customers to buy } \\
\text { a new pass regularly } \\
\text { - Require customers to prove their eligibility to keep a low-income } \\
\text { pass every } 6 \text { months } \\
\text { - Require that the low-income smart card expires after } 24 \text {-months } \\
\text { - Include a name and photo on the pass }\end{array}$ \\
\hline
\end{tabular}

\section{Discussion}

The analysis of US fare programs demonstrated that agencies providing first generation fare subsidy programs have similar ranges in operating cost, service size, and bus operations to agencies that provide targeted strategies. The data demonstrated that even relatively small agencies, in terms of operating expenses and bus fleet size, can provide targeted fare programs. This is possible partly because of agency partnerships. For example, while the ORCA LIFT program is managed by King County Metro, geographically close smaller agencies such as Intercity Transit also recognize ORCA LIFT, additionally benefiting their low-income riders. However, the analysis results did not identify any distinct differences in characteristics that might suggest why agencies with the resources or ability to provide targeted low-income strategies are not yet doing so. One reason may be that first generation fare programs are easier to operate and require less sophisticated technology. Another reason could be a lack of education. Not all transit agencies may be familiar with how to approach inclusion or exclusion issues or be aware these issues exist.

The case studies revealed that while some policies are well-intentioned, they may be subject to some of the inclusion or exclusion problems described earlier. The Heritage Community Transportation program in Pennsylvania is an example of this. Conversely, both the King County Metro and TriMet case studies showed how targeted strategies that avoid inclusion and exclusion issues operate in the United States. These case studies also showed that a targeted low-income strategy can have a marginal impact on overall operating expenses. 
An examination of current practices revealed that low-income is defined differently by different agencies. This is possibly because local cost of living variations impact how affordable transit is to low-income populations. Defining low-income as $150 \%$ of the federal poverty line might work in Portland, Oregon, but it might not work in a place with a comparatively higher cost of living, such as King County, Washington. Current practices also showed there can be many methods for identifying low-income populations, but these varying methods also have varying levels of administrative effort. For example, showing a food stamps card with photo identification may require less administrative effort than proving income with paystubs. As the TriMet case study demonstrated, some of this effort can be allocated to partner organizations to reduce the administrative workload for transit providers. The Heritage Community Transportation program, although not a targeted subsidy program, also highlighted potential financial benefits for regional transit partnerships.

The review of current practices also found there are transit agencies that can provide targeted fare strategies without using smart cards for fare payment. This is a key finding as the literature identified fare technology as a primary factor in the uptake of targeted fare programs. The agencies identified either provided a lowincome identification card enabling customers to obtain a cheaper transit pass when purchasing their fare, or they partnered with low-income organizations to distribute discounted fares. The first of these methods was observed in three different agency fare programs across the United States.

Agencies providing targeted fare programs have tried a variety of methods to avoid fraud. However, achieving this is ultimately a trade-off between the impact to an agency, both administratively and financially, and the impact to the customer. Developing a fraud-risk strategy that works might harm the riders the organization is trying to benefit. For example, while an agency requirement to frequently prove eligibility may reduce the risk of financial loss, it could make the benefit less accessible to low-income riders with limited mobility options. Consequently, agencies need to consider this issue and their program goals when developing a fraud-risk strategy.

\section{Conclusions}

Vertical equity and the maximization of farebox revenue are both important goals in the development of fare policy in the United States. However, these goals conflict with each other. Reducing fares for low-income populations reduces available revenue for a transit agency, while increasing fares to increase revenue could disproportionately impact lower-income communities. Consequently, this paper has detailed the vertical equity and farebox revenue trade-off before exploring different strategies that could be implemented to account for both goals. These strategies need to ensure both accessibility and financial sustainability.

Many of the first generation strategies included individuals who did not require fare assistance or excluded those who did. Part of the limitation of these strategies was a poor understanding of the target population or inadequate methods for targeting this population. Targeted subsidy programs developed as these two issues improved. Smart card technology, in particular, has enabled transit agencies to target specific populations for different policies. These developments demonstrate that if transit agencies want to implement policies that account for low-income populations, they need to specifically identify what constitutes low-income and be sure they can reach this specific group through policy.

In the United States, many transit agencies and other organizations have attempted to provide fare strategies addressing low-income ridership with varying levels of success. An evaluation of fare programs demonstrated that partnerships are important. Agencies can partner together, pooling resources, to reduce the impact of implementing a targeted low-income fare strategy. For example, a smart card could be designed to work in multiple geographically close service areas. Transit agencies can also partner with other organizations that 
may provide financial or administrative assistance. In addition, existing US programs have demonstrated the importance of understanding local populations when developing a fare strategy. Defining low-income thresholds should differ based on local income levels. The evaluation showed that, while smart cards and other technology can be useful for developing targeted strategies, they are not required. Finally, the case studies revealed that targeted programs can be successfully implemented without generating substantial financial impacts.

In conclusion, this paper has demonstrated that although vertical equity and farebox recovery are opposing fare policy goals, both can be accounted for through strategies that treat low-income populations separately. And, although strategies achieving these goals have been developed and changed over time, they have the potential to improve even more as methods for understanding and targeting low-income populations improve. As technology such as mobile ticketing advances, dynamic fare pricing may allow more effective, means-tested fares that allow transit agencies to manipulate fares while minimizing impacts to vulnerable customers.

There are several avenues for further research in this area. First, although the analysis of US fare programs provided some insights into different agency characteristics, no characteristic was identified as a distinguisher between first generation and targeted strategies. More work could be done to determine why some agencies with the means to provide targeted strategies currently do not. In addition, as the case studies showed, there are opportunities to explore relationships between transit agencies and other partners in the provision of lowincome fare programs. Future research could consider how to develop strategic partnerships with employers or other organizations supporting low-income populations.

\section{Acknowledgements}

The author would like to acknowledge the help of Dr. Martin Pietrucha, who encouraged this work and provided preliminary feedback on the paper's discussion.

\section{References}

APTA (American Public Transportation Association). 2007. Public Transportation: Benefits for the 21st Century. https://www.apta.com/resources/reportsandpublications/Documents/twenty_first_century.pdf.

Beimborn, E. A., M. J. Greenwald, and X. Jin. 2003. "Accessibility, Connectivity, and Captivity Impacts on Transit Choice." Transportation Research Record: Journal of the Transportation Research Board 1835: 1-9. doi:10.3141/1835-01.

Bueno Cadena, P. C., J. M. Vassallo, I. Herraiz, and M. Loro. 2016. "Social and Distributional Effects of Public Transport Fares and Subsidy Policies: Case of Madrid, Spain." Transportation Research Record: Journal of the Transportation Research Board 2544: 47-54. doi:10.3141/2544-06.

Camporeale, R., L. Caggiani, A. Fonzone, and M. Ottomanelli. 2017. "Quantifying the Impacts of Horizontal and Vertical Equity in Transit Route Planning." Transportation Planning and Technology 40 (1): 28-44. doi:10.1080 /03081060.2016.1238569.

Community Transportation Association. 2011. "Chart of Transportation Reduced Fare and Free Fare Programs to Serve Low-Wage Earners." Accessed February 15, 2017. http://web1.ctaa.org/webmodules/webarticles/ articlefiles/Chart_ReducedFareAndFreePrograms.pdf. 
Criden, M. 2008. The Stranded Poor: Recognizing the Importance of Public Transportation for Low-Income Households. Washington, DC: National Association for State Community Services Programs.

Fleishman, D. 2012. “Fare Collection 101: Fare Policy.” Presentation to APTA 2012 Fare Collection Workshop, March 21, 2012. http://www.apta.com/mc/fctt/previous/2012/fcpresentations/Presentations/FareCollection-101-Fare-Policy.pdf.

FTA (Federal Transit Administration). National Transit Database. 2013. King County Department of Transportation - Metro Transit Division (King County Metro). https://www.transit.dot.gov/ntd/transitagency-profiles/king-county-department-transportation-metro-transit-division.

_ 2014. Tri-County Metropolitan Transportation District of Oregon (TriMet). https://www.transit.dot.gov/ ntd/transit-agency-profiles/tri-county-metropolitan-transportation-district-oregon-trimet.

GAO (US General Accounting Office). 2001. Transit Labor Agreements: Most Transit Agencies Report Impacts Are Minimal. GAO-02-78. Washington, DC.

Gomez-lbanez, J. A. 1996. "Big-City Transit Rider snip, Deficits, and Politics: Avoiding Reality in Boston." Journal of the American Planning Association 62 (1): 30-50. doi:10.1080/01944369608975669.

Gray, G. E., and L. A. Hoel, editors. 1992. Public transportation: $2^{\text {nd }}$ ed. Englewood Cliffs, NJ: Prentice Hall.

Heritage Community Initiatives. 2012. "Heritage Community Transportation." Accessed April 25, 2016. http:// www.heritageserves.org/heritage-transportation.html.

King County Metro. 2014. Report on Transit Fares. Seattle, WA: King County Department of Transportation. http://metro.kingcounty.gov/am/reports/2014/transit-fares-report.pdf.

_ 2015. 2014 Rider Survey Final Report Summary. Seattle, WA: King County Department of Transportation. http://metro.kingcounty.gov/am/reports/2014/2014-rider-survey-summary.pdf.

Kneebone, E., and N. Holmes. 2015. The Growing Distance between People and Jobs in Metropolitan America. Washington, DC: Metropolitan Policy Program at Brookings.

Kockelman, K., T. D. Chen, K. Larsen, and B. Nichols. 2013. The Economics of Transportation Systems: A Reference for Practitioners. TxDOT Project 0-6628. Center for Transportation Research, University of Texas at Austin.

Lindquist, K., M. Wendt, and J. Holbrooks. 2009. Transit Farebox Recovery and US and International Transit Subsidization: Synthesis. Olympia, WA: Public Transportation Office, Washington State Department of Transportation.

MBTA (Massachusetts Bay Transportation Authority). n.d. Frequently Asked Questions: Farebox Recovery. https://cdn.mbta.com/sites/default/files/2017-10/panel-report-faqs-farebox-recovery.pdf.

Mehndiratta, S., C. Rodriguez, and C. Ochoa. 2014. Targeted Subsidies in Public Transport: Combining Affordability with Financial Sustainability. Washington, DC: World Bank Group.

Multisystems, Inc. 2003. Fare Policies, Structures and Technologies: Update. Transit Cooperative Research Program (TCRP) Report 94. Washington, DC: Transportation Research Board.

Oestreich, H., and G. Whaley. 2001. Transit Labor Relations Guide. Mineta Transportation Institute Report 01-02, San José State University. 
Taylor, B. D., and C. N. Y. Fink. 2003. "The Factors Influencing Transit Ridership: A Review and Analysis of the Ridership Literature." Working Paper. University of California Transportation Center, UC Berkeley. Accessed April 21, 2016. http://escholarship.org/uc/item/3xk9j8m2.

Transportation for America. n.d. "Heritage Community Initiatives - Connecting Residents of the Mon Valley to Jobs." Accessed April 21, 2016. http://t4america.org/maps-tools/local-successes/heritage-communitytransportation/.

TriMet. n.d.a. "Access Transit Low-Income Fare Programs." Accessed April 25, 2016. http://trimet.org/ accesstransit/index.htm.

n.d.b. “Fair and Equitable Transit." Accessed April 25, 2016. http://trimet.org/equity/access.htm.

- 2016a. Proposed Budget 2016-2017. Tri-County Metropolitan Transportation District of Oregon. Accessed April 25, 2016. https://trimet.org/budget/pdf/2017-proposed-budget.pdf.

_.2016b. TriMet Attitude and Awareness Survey. Accessed March 30, 2017. https://trimet.org/pdfs/ publications/TriMet-Attitude-Awareness-Survey-2016.pdf.

US Census Bureau. 2016. Income and Poverty in the United States: 2015. Accessed March 30, 2017. https://www. census.gov/library/publications/2016/demo/p60-256.html.

Urban Transport Group (former Passenger Transport Executive Group). 2010. The Effect of Bus Fare Increases on Low Income Families. Accessed April 25, 2016. http://www.urbantransportgroup.org/system/files/ Effectofbusfareincreasesonlowincomefamilies.pdf.

\section{About the Author}

Xavier Harmony (xjharmony@gmail.com) is a senior transportation analyst at the Northeast Corridor Commission where his work focuses on operations and finance for passenger rail. At the time this work was completed, he was a Transportation Engineering master's candidate at the Pennsylvania State University. 